\title{
Hvad er ledelse af brugerinddragelse? En gennemgang af mål og tre individuelle brugerinddragelsesmodeller
}

\section{Christina Holm-Petersen og Laura Emdal Navne}

KORA

Institut for Folkesundhedsvidenskab

chpe@kora.dk,lana@sund.ku.dk

Holm-Petersen, C. \& Navne, L.E. (2015). Hvad er ledelse af brugerinddragelse? En gennemgang af mål og tre individuelle brugerinddragelsesmodeller, Tidsskrift for Forskning i Sygdom og Samfund, nr. 22, 103-133.

Brugerinddragelse $i$ det danske sundhedsvæsen står højt på den politiske dagsorden, men det er stadig en udfordring at implementere visionen i klinisk praksis. Ledelse af brugerinddragelse bliver aktuelt udpeget som en central nogle til at fore visionen ud i livet. Samtidig er der kun relativt lidt forskning om ledelse af brugerinddragelse i sundhedsvæsenet og pa det empiriske plan er det uklart, hoad det er lederne skal implementere. Artiklen identificerer syv forskellige italesatte mål med brugerinddragelse, hvoraf nogle potentielt kan være $i$ konflikt med hinanden. Herudover peges der på, at brugerinddragelse skal implementeres $i$ en verden, hoor der allerede er en række andre mål tilstede. En central ledelsesudfordring er derfor, at nogle af målene med brugerinddragelse forudsætter nye måder at organisere ikke bare arbejdet og kompetencer $p a ̊$, men også relationer til patienter og pårorende. En væsentlig opgave i ledelse af brugerinddragelse vil derfor være at fremme en gentænkning af de etablerede roller og identiteter $i$ sundhedsvasenet. Artiklen opstiller tre forskellige 
inddragelsesmodeller, der hver organiserer relationer mellem sundhedsprofessionelle og sundhedsvæsenets brugere på forskellige måder.

Artiklen bygger dels på en gennemgang af dansk og international litteratur og policy dokumenter, dels på en empirisk best practice undersøgelse af ledelse af brugerinddragelse, som i perioden 2012-2013 blev gennemført på tre danske hospitalsafdelinger.

\section{How to lead patient involvement? Goals and models that organize relations}

Patient involvement in the health services in Denmark is high on the political agenda, though continues to be a challenge to implement. It is increasingly said that leadership is crucial to the implementation process. However, research into the role of leaders in patient involvement in the health care sector is sparse, and on the empirical level it is still unclear what the leaders are to implement. This article identifies seven different goals that have been enacted in the literature and policy papers, some of which potentially conflict with each other. It is further pointed out that patient involvement is to be implemented into a world in which a variety of other goals already exist. A major leadership challenge is therefore that some of the goals with patient involvement require new ways of organizing not just work practices and competencies but also relations with users. A key leadership task in management of patient involvement is therefore to reinvent established roles and identities in the health care sector. The article puts forward three models of involvement, which organize relations between health care professionals and health care users in various ways.

This article is based on existing Danish and international literature and policy documents on patient involvement, and on an empirical investigation of how patient involvement is implemented by clinical leaders, which we carried out in 2012-2013 in three Danish hospital wards identified as best practice cases.

\section{Indledning}

Visionen om at skabe mere brugerinddragelse i sundhedsvæsenet står stærkt blandt politiske beslutningstagere, men trods mere end tyve års fokus på brugerinddragelse er det stadig uklart, hvilket indhold forskellige aktører lægger i begrebet brugerinddragelse. Det er også uklart, hvad der skal til for at komme ud over projektstadiet og implementere initiativer i klinisk praksis. Det generelle billede i litteraturen er, at brugerinddragelse er en kronisk udfordring at implemen- 
tere (Coulter 2011, 2012; Elwyn et al. 2013; Edwards \& Elwyn 2009; Bate \& Robert 2006; Jacobsen, Pedersen \& Albeck 2008; Rahbek \& Rønberg 2010; Freil \& Knudsen 2009; Holm-Petersen \& Navne 2013).

Der er i den teoretiske litteratur mange eksempler på, hvad det er for udfordringer implementering af brugerinddragelse møder i sundhedsvæsenet. Udfordringerne kan inddeles i tre hovedkategorier. Den første kategori handler om fagprofessionel modstand. Fagprofessionerne har flere argumenter for, hvorfor brugerinddragelse i form af fx fælles beslutningstagning er en mindre god idé (Coulter 1997, 2011; Edwards \& Elwyn 2009; Elwyn et al. 2013; Jacobsen et al. 2008). Nogle af disse argumenter handler om: A) At der ikke er tid i et effektiviseret sundhedsvæsen (Coulter 1997; Price 2009; Elwyn et al. 2013; Rahbek \& Rønberg 2010; DSI 2000; ViBIS 2013, Mandag Morgen 2014). B) At fælles beslutningstagning ikke er fagligt relevant (Elwyn et al. 2013; Wiig et al. 2013). Fx hvis der kun er evidens for én måde at beslutte på - eller hvis det ikke passer ind i den kliniske situation (Price 2009; ViBIS 2013). Det er ikke altid fagprofessionelle anerkender patientpræferencer som betydningsfulde eller legitime (Jacobsen et al. 2008) og der kan være en bekymring for, at de stærkeste patienter vil efterspørge mere på de svagestes regning (Coulter 1997). Samt C) At fælles beslutningstagning ikke er i patienternes interesse (Coulter 1997; Rangachari, Bhat \& Seol 2011; ViBIS 2013). Ud fra argumenter om at patienter ikke kan overskue for megen information (Coulter, 1997; ViBIS, 2013), at det ikke er etisk korrekt at informere for meget, eller at det indebærer for meget ansvar på patientens skuldre at deltage i svære beslutninger (Coulter 1997; Elwyn et al. 2013). En undersøgelse har fx vist, at kirurger og patienter er enige i deres vurdering af, hvornår patienten ikke ønsker lægens direkte og ærlige vurdering ved brystkræft, da der skal være plads til håb (Mendick, Young, Holcombe \& Salmon 2011).

Anden hovedkategori handler i forlængelse heraf om patientmodstand og kompleksitet. Diskussionen handler her ofte om, at det ikke er alle patienter, der er lige interesserede i eller velegnede til at indgå i patientinddragelsesrelationer. Det giver eksempelvis ikke mening at forvente, at en bevidstløs patient eller en nyfødt patient er aktivt inddraget. Både sygdomssituation og sygdomstilstand kan således have betydning for, hvorvidt det er muligt eller hensigtsmæssigt at inddrage (DSI 2000; Coulter 1997; Entwistle, Sowden \& Watt 1998; Price 2009). Patientens alder kan også påvirke ønsker til inddragelse (Coulter 1997). Der vil være patienter, der ikke ønsker at deltage aktivt i beslutninger eller behandling, men der vil også være patienter som ikke udstråler, at de ønsker at deltage eller tager initiativ til at deltage, men som gerne vil, hvis de får præsenteret muligheden, eller hvis fagpro- 
fessionelle omkring dem understøtter dem heri (Pedersen 2011; Anderson 2005). Patienter værdsætter ofte mere information, end lægen tror (Coulter 1997, 2011; Jacobsen et al. 2008; Entwistle et al. 1998; DSI 2000) og ville i højere grad deltage, hvis problemstillingerne blev bredere præsenteret (Entwistle, Cribb \& Watt 2012). Undersøgelser peger således på, at der er patienter, der sandsynligvis ville deltage, hvis rammerne for deltagelse var mere tydeligt til stede og dermed indbød til at deltage. Rollerne som aktive patienter skal være tydelige og oplagte, ellers opdager og indtager patienterne dem ikke (Jacobsen \& Petersen 2009). Patientens modstand mod at opsøge og modtage information, der kan bekymre, er en anden udfordring, som litteraturen peger på (Jacobsen et al. 2008; Mendick et al. 2011). Patienters håbsarbejde (Mattingly 2010; Hansen \& Tjørnhøj-Thomsen 2014) kan fx øge kompleksiteten i, hvornår det er hensigtsmæssigt at dele hvilke informationer. Begrebet brugerinddragelse må gradbøjes og fortolkes og kan ikke være universelt gældende. Et overordnet skifte i perspektiv på den primære patientrolle kan dermed ikke automatisk omsættes til en ny standardiseret form for praksis, som skal udrulles henover alle patientforløb på én og samme måde.

Strukturelle barrierer og styringsvilkår er en tredje type af udfordringer, der eksempelvis handler om incitamentsstrukturer og økonomiske afregningsmodeller (Holm-Petersen \& Navne 2013). Som led i den økonomiske styring af sundhedsvæsenet er en række ydelser standardiseret og defineret på forhånd. Der er således et indbygget paradoks i på den ene side institutionaliserede generelle problemkategorier, professionelle løsningsmodeller og afregning og på den anden side individuelle hensyn (Järvinen \& Mik-Meyer 2003) og forestillinger om et faciliterende væsen, der understøtter individuelle behov (Anderson 2005, 2010). På det overordnede plan løber individuel brugerinddragelse således ind i en grundlæggende spænding mellem universalisme og partikularisme (Hoggett 2006) samt offentlige organisationers opgave med at rationere offentlige ydelser (ibid.). Målet med en række af de effektiviserings- og standardiseringstiltag, der er blevet implementeret i sundhedsvæsenet, er at tilgodese brugernes interesse dels ved at sikre hurtig behandling (pakkeforløb, ventetids- og udredningsgarantier), dels ved at søge at fremme kvalitet (kvalitetsstandarder, kliniske retningslinjer). Endelig er der målet om at holde udgifterne nede, som i en velfærdskollektiv optik kan komme brugerne (som skatteydere) til gode. Der er indkøbsaftaler, der holder udgifter nede, men samtidig begrænser valgmuligheder. DRG-takster og lignende afregningssystemer er samtidig med til at definere, hvad der er relevante og for systemet givende (produktive) opgaver. Struktur- og styringslogikker i disse former er designet til at tilgodese brugerens overordnede interesser, men kan i 
det konkrete komme til at hæmme muligheden for at opfylde individuelle behov. Standardisering kan dermed modvirke den individuelle brugerinddragelse (Freil \& Kjær 2012; Jest 2005; Knudsen \& Bentsen 2010). Manglen på egnede fysiske rum til inddragelse er en anden type af institutionel barriere (DSI 2000).

Udfordringerne er mange og velbeskrevne. Det, der mangler viden om, er, hvordan det på trods af udfordringerne er muligt at komme videre med at implementere brugerinddragelse. Forskere inden for brugerinddragelsesfeltet har for nylig peget på, at implementering af brugerinddragelse i højere grad skal defineres som en vigtig ledelsesopgave (Coulter 2011; Kjær \& Pedersen 2010; Freil \& Kjær 2012; Rangachari, Bhat \& Seol 2011). Danske Regioner understregede i deres sundhedsudspil fra 2013 behovet for "at udvikle helt nye ledelsesmodeller, der kan håndtere ledelse på tværs af faggrupper, organisationer og sektorer og som kan rumme tværfaglighed, patientinddragelse og fokus på kvalitet" (Danske Regioner 2013). Regeringen skriver i deres seneste sundhedsudspil, at ledelse og nye kompetencer er vigtige i omstillingen til en mere patientinddragende tilgang (Regeringen 2014). Videnscenter for Brugerinddragelse konkluderer, at patientinddragelse er et ledelsesansvar (ViBIS 2013). Sundhedsvæsenets ledere på alle niveauer opfordres til at spille en mere aktiv rolle, hvis visionen skal implementeres (Holm-Petersen \& Navne 2013; Ministeriet for Sundhed \& Forebyggelse 2014). I Norge peges der på, at ledere på hospitaler skal udvikle strategier for at formidle vigtigheden af inddragelse for de fagprofessionelle (Wiig et al. 2013). Det amerikanske Joint Commission har i tråd hermed understreget behovet for, at ledere arbejder med at opbygge kulturer, der i højere grad sikrer en inddragende kommunikation med patienter og dermed kvalitet og patientsikkerhed (The Joint Commission 2007). En udfordring er her, at der er meget få empiriske undersøgelser af, hvordan ledelse i praksis kan understøtte implementering af brugerinddragelse. En udfordring er også, at der synes at være forskellige mål med at italesætte behovet for mere brugerinddragelse. Det vanskeliggør potentielt ledelsesopgaven med at få brugerinddragelse ud i klinisk praksis for, hvad er det, lederne, medarbejderne og patienterne skal opnå? Og hvordan kan man håndtere flere og måske modsatrettede mål?

I denne artikel identificerer vi syv forskellige mål med brugerinddragelse, og i forlængelse heraf formulerer vi tre modeller for individuel brugerinddragelse, der iscenesætter relationer mellem brugere og fagpersoner på forskellige måder. De tre modeller kan i tråd hermed forventes at afføde forskellige implementeringsudfordringer. Modellerne er udledt på baggrund af litteratur om brugerinddragelse og har indgået som led i caseudvælgelsen til en empirisk undersøgelse vi gennemførte i perioden 2012-2013 på tre hospitalsafdelinger om best practice 
ledelse af brugerinddragelse (Holm-Petersen \& Navne 2013). Målene med brugerinddragelse er udledt af en litteratursøgning i policy dokumenter fra de centrale aktører på området gennemført i 2012, centrale teoretiske referencer på brugerinddragelsesområdet samt en gennemgang af litteratur om ledelse af brugerinddragelse. Der er herunder ved hjælp af sneboldsmetoden i perioden 2012-2013 søgt på dansk, svensk, norsk og engelsksproget litteratur om ledelse, organisering og implementering af brugerinddragelse. Søgningerne førte i alt til ca. 200 relevante artikler, bøger og dokumenter, som vi vurderede at dække de væsentligste og mest citerede udgivelser.

\section{Hvad er ledelse af brugerinddragelse?}

Der findes mange definitioner af de beslægtede begreber brugerinddragelse, patientinddragelse, patientinvolvering $\mathrm{mm}$. Brugerinddragelse er et begreb, der er omgivet af fortolkningsmæssig fleksibilitet og anvendes i artiklen som et synonym for patient- og pårørendeinddragelse. Begrebet bruger vandt indpas i begyndelsen af 1990'erne samtidig med et opgør med klientliggørelse samt tiltagende kritik af den ulighed og afhængighed, man forbandt med patientrollen. Brugerbegrebet skulle henvise dels til demokratisk deltagelse på den ene side og forbrugerens ret til det frie valg i den frie konkurrence på den anden side (Timm 1997; Pedersen 2008). Indførelsen af frit sygehusvalg i 1992 er et eksempel. Flere forskere og praktikere har gennem årtier argumenteret for at anvende et andet ord end patient (som betyder den tålmodige) for at signalere, at der er tale om en ny arbejdsdeling. I den klassiske professionssociologi beskrives den fagprofessionelle som uselvisk, objektiv og neutral (Brante 1988) og som en vidende og kurerende "redningsmand" (Lupton 1994). Patienten og dennes krop er derimod det "objekt", den fagprofessionelle udfører sin gerning på. Talcott Parsons beskriver i sin berømte analyse af "The sick role", hvordan der følger en række rettigheder og pligter med sygerollen (Parsons 1939; Pedersen 2008). Den syge forventes at forblive passiv og compliant eller aktiv på lægens indikation. Lægens rolle er derimod den vidende og handlende autoritet. I denne relation spiller den passive patient en støtterolle til den handlende professionelle, som i princippet har fået overdraget råderet over patientens krop eller sind. I den voksende egenomsorgslitteratur, der især har taget fart gennem de seneste 10 år, anses patienten for hovedansvarlig for eget helbred gennem aktivt engagement i egen pleje og behandling. I denne rela- 
tion overdrager den professionelle i høj grad patienten ansvaret for at tage vare på egen krop (Hibbard \& Cunningham 2008, Hibbard et al. 2007; Pedersen 2008).

Det er på denne vis muligt at lægge forskellige forståelser af arbejds- og rollefordeling mellem patient, pårørende, den fagprofessionelle og sundhedsvæsenet ind i begrebet. Dette hænger, som vi vil argumentere for, sammen med, at forskellige aktører har forskellige mål med brugerinddragelse. Ledere, som skal iværksætte brugerinddragelse, står derfor med den udfordring at mediere, omsætte og nogle gange forene disse mangeartede mål og potentielle forskellige roller, identiteter og interesser.

\section{Ledelse der skaber retning}

I såvel den danske som den internationale litteratur om patient- og pårørendeinddragelse i behandling findes kun få empiriske eksempler på, hvad ledelse af brugerinddragelse er. Ledelse af brugerinddragelse handler på det mere abstrakte plan ifølge to danske ledelses- og organisationsforskere om at organisere patienten og definere patientskabet og forme det $\mathrm{i}$ forhold til den konkrete kliniske virkelighed (Kjær \& Reff 2010). Der er også blevet peget på, at det er op til lederne at skabe rammer, sætte mål og retning for brugerens og de fagprofessionelles interaktion og gensidige forståelser. Ledelsen opfordres fx til at insistere på, at fagpersoner lytter til, støtter og inddrager patienter, deres viden og deres ressourcer (Freil \& Kjær 2012). Institute for Healthcare Improvement (IHI) foreslår at fremme patient eller person centered care gennem en ny mental ledelsesmodel, hvor ledere kontinuerligt fokuserer på og italesætter behandling og pleje ud fra patientbehov (Swensen et al. 2013).

Litteraturen foreslår endvidere, at ledere kan skabe retning og vilkår for brugerinddragelse ved at ansætte, efteruddanne og belønne medarbejdere ud fra værdier om brugerorientering plus visionært og effektivt at have fokus på patienters og pårørendes værdier og præferencer i deres kommunikation med medarbejderne (Coulter 2011). Ledere anses for at være i en position, hvor de kan sikre de rammer, der understøtter de sundhedsprofessionelle og patienterne i at påtage sig de (nye) roller som henholdsvis facilitator og aktiv patient (Entwistle et al. 2010; Mendick et al. 2010; Anderson 2005, 2010), følge op med gentænkning af arbejdsorganisering (Rangachari et al. 2011; Mendick et al. 2010, 2011), ressourceallokering og problemløsning (Wagner et al. 2001) og eventuelle efteruddannelsestilbud til personalet (Navne, Nielsen \& Jacobsen 2011). I den empiriske undersøgelse af ledelse af brugerinddragelse, som vi gennemførte i 2012-2013, ses ledelsen som 
havende en vigtig rolle som dem, der sætter mål for brugerinddragelse, definerer brugerinddragelse som en arbejdsopgave, skaber de nødvendige rammer, herunder for kompetenceudvikling og selv går foran som rollemodeller (Holm-Petersen \& Navne 2013). Der er argumenteres i samme undersøgelse for, at brugerinddragelse bør organiseres, ledes og diskuteres som en opgave, der kræver professionelle kompetencer og understøttende systemer (ibid.).

\section{Mål med brugerinddragelse}

De aktuelle sundhedspolitiske diskurser er fyldt med forskellige visioner for brugerinddragelse. Brugerinddragelse udspringer nemlig både af administrative og økonomiske behov og af demokratiske behov (Hoff 1997; Pedersen 2008). I tråd hermed argumenterer vi for, at brugerinddragelse i sundhedsvæsenet i praksis bliver genstand for mange forskellige mål, behov, interesser og dagsordener i såvel klinik som sundhedspolitik. Ofte argumenteres der for flere af disse mål med brugerinddragelse samtidigt. Det er fx tilfældet i visionspapiret: Borgerens sundhedsvæsen. Her argumenterer centrale aktører for, at brugerinddragelse både skal føre til bedre kvalitet, målrettet og effektiv anvendelse af ressourcer og udvikling af nye og effektive tilbud (Danske Patienter, Kommunernes Landsforening, Sundhedsstyrelsen \& Danske Regioner 2013). I det følgende gennemgår vi syv forskellige mål med brugerinddragelse, vi har identificeret dels i aktuelle sundhedspolitiske diskurser, dels i den teoretiske litteratur om brugerinddragelse. Det fremgår, at de forskellige mål indebærer forskellige implementeringsudfordringer for ledere og forskellige måder at organisere relationen til patienter og pårørende på. Forskellige mål indebærer forskellige arbejdsdelinger, roller og gensidige identiteter (Gergen 1997).

\section{Mål 1: Ligeværdig deltagelse (partner)}

En drivkraft i forhold til at tale om brugerinddragelse har været et demokratisk ideal om, at patienter er mennesker med rettigheder, meninger og perspektiver på egen krop og sjæl, som har krav på ligeværdig deltagelse (Guadagnoli et al. 1998). I dette perspektiv er det naturligt, at patienter og borgere inddrages i beslutninger med betydning for den enkeltes liv og helbred. Dette mål er centralt i den forskningsmæssige litteratur på området (Elwyn et al. 2013; Edwards \& Elwyn 2009; Coulter 1997, 2011; Entwistle et al. 2012) og kan genfindes i policy do- 
kumenter. Danske Patienter, KL, Sundhedsstyrelsen og Danske Regioner skriver eksempelvis, at borgernes viden skal anerkendes som nødvendig og ligeværdig, og at borgeren skal inddrages reelt i beslutninger (Danske Patienter et al. 2013). For nyligt er sloganet: "Min behandling-min beslutning" blevet lanceret (Regeringen 2014; Ministeriet for Sundhed og Forebyggelse 2014). Det er også blevet fremført, at der skal være bedre mulighed og forudsætninger for en mere ligeværdig dialog mellem patient og behandler (Det Nationale Råd for Kvalitetsudvikling 2002). Patienten som ligeværdig partner sætter fokus på, hvordan patient og behandler kan samarbejde om at forebygge sygdom og skabe gode behandlingsresultater. Fokus er her på foreningen af patientens og behandlerens viden og kompetencer. Idealet er højst mulig ligeværdighed. Det fælles mål er den bedst mulige kvalitet i den enkeltes behandling. Ifølge nogle policy dokumenter kan fokus på ligeværdig inddragelse også modvirke social ulighed i behandlingen (Regeringen 2014; Ministeriet for Sundhed og Forebyggelse 2014). Centralt for partnerskabsparadigmet er den såkaldte "fælles beslutningstagning", som er en model for, hvordan patienter og behandlere kan samarbejde om at træffe de bedst mulige behandlingsvalg for patienten (Edwards \& Elwyn 2009; Jacobsen et al. 2008).

En udfordring for målopfyldelse er, at målet forudsætter en ændring i de faglige identiteter og den fagprofessionelle kultur, hvor kontrol over eget arbejde er et bærende element. Essensen af det fagprofessionelle fællesskab er netop en stærk tro på, at det kun er fagprofessionens egne medlemmer, der har den rigtige viden, færdigheder og fokus til at kunne afgøre, hvordan arbejdet skal udføres og evalueres (Abbott 1988; Freidson 1983, 1986; Van Maanen \& Barley 1984). De sundhedsprofesionelles fagidentitet levner dermed ikke plads til patienternes viden (Jacobsen i ViBIS 2012:7). Målopfyldelse er således afhængig af opbyggelsen af nye mentale modeller (Swensen et al. 2013; Rangachari et al. 2011).

\section{Mål 2: Bedre kvalitet og patientsikkerhed}

At brugerinddragelse skal føre til bedre kvalitet er et centralt mål i policy dokumenter (Danske Patienter et al. 2013; Danske Regioner 2013; Region Hovedstaden 2007; Region Midtjylland 2010; Region Nordjylland 2012; Regeringen 2013, 2014; Ministeriet for Sundhed og Forebyggelse 2014; Sundhedsstyrelsen 2005; Det Nationale Råd for Kvalitetsudvikling 2002) og er indarbejdet i Den Danske Kvalitetsmodel version 2. Samtidig ses brugerinddragelse som en vej til at udvikle nye og mere effektive tilbud (Danske Patienter et al. 2013). Målet om bedre kvalitet er også centralt i den teoretiske litteratur om brugerinddragelse (Coulter 1997, 2011; Edwards 
\& Elwyn 2009; Elwyn et al. 2013; Anderson et al. 1995; de Silva 2014; Weingart et al. 2011; Hibbard et al. 2008; Greenfield et al. 1985). I denne optik ses det traditionelle patientsyn (den passive patient) som en udfordring for at opnå effektive resultater for patienterne såvel som for compliance. Hvis ikke patienten forstår, hvorfor han/ hun skal tage medicin, hvis ikke patienten er motiveret for at tage sin medicin osv., så får fraværet af brugerinddragelse konsekvenser for outcome, sygelighed og dødelighed. Omvendt kan brugerinddragelse føre til bedre compliance (Robinson et al. 2001; Hibbard et. al. 2007; Jacobsen et al. 2008; ViBIS 2013; Region Syddanmark 2011). Der er dog ikke enighed om, hvorvidt compliance er vejen til bedre kvalitet $\mathrm{i}$ en brugerinddragelsesoptik. Bedre kvalitet kædes i forskningen ofte sammen med mål 1 om ligeværdig deltagelse. Øget patientautonomi (med øget handlekraft, selvstændighed, selvværd) anses her som en forudsætning for at skabe bedre kvalitet i sundhedsvæsenet (Coulter 1997, 2011; Edwards \& Elwyn 2009; Elwyn et al. 2013; Anderson et al. 1995). Brugerinddragelse har fx ført til øget kvalitet i diabetesbehandling (Anderson et al. 1995; Coulter 2011), hjerte- og lungesygdomme, apopleksi, gigt og depression (Rangachari et al. 2011).

Brugerinddragelse diskuteres i tråd med bedre kvalitet som en vej mod øget patientsikkerhed (Entwistle et al. 2010; Vincent \& Coulter 2002; Schwappach 2009; Davis et al. 2007; Weingart et al. 2011; Rahbek \& Rønberg 2010; Martin \& Larsen 2012; Institute of Medicine 2000; Joint Commission Ressources 2006; Region Midtjylland 2010; Ministeriet for Sundhed og Forebyggelse 2014; Det Nationale Råd for Kvalitetsudvikling 2002). Dansk selskab for Patientsikkerhed og internationale søsterorganisationer advokerer for, at dette kan realiseres ved, at patienter og pårørende involverer sig aktivt i patientsikkerhed, fx ved at gøre opmærksom på fejl i deres forløb (Andersen, Lipczak \& Ammundsen 2011). Forskning i involvering af kræftpatienter i patientsikkerhed peger dog på, at sikkerhed sjældent italesættes i mødet mellem patienter og sundhedsprofessionelle, at patienterne har andre mere presserende bekymringer, samt at patientens rolle i patientsikkerhed af begge parter fortolkes som et spørgsmål om compliance og selv-monitorering, ikke fjernt fra den traditionelle patient-rolle (Martin, Navne \& Lipczak 2013). Sundhedsprofessionelle udtrykker bekymring for, at involvering af kræftpatienter i patientsikkerhed kan bidrage til yderligere psykisk belastning i krisesituationer og muligvis til tab af tillid (ibid.). Studier peger på, at en forudsætning for at øge patientsikkerhed gennem brugerinddragelse synes at være, at sundhedsprofessionelle opmuntrer til og støtter patienter heri (Davis 2002, Entwistle et. al. 2010; Andersen, Lipczak \& Ammundsen 2011; Martin \& Larsen 2012), samt at der udvikles redskaber og vejledninger til, hvordan det kan gøres (Martin, Navne \& Lipczak 2013). Hvis den 
gensidige relation ikke understøtter, at patientens observationer mødes positivt, kan inddragelse føre til øgede patientbekymringer og -skade (Entwistle et al. 2010). Det er ikke entydigt, om målet med bedre kvalitet forudsætter en ændring i de gensidige identiteter mellem patient og fagprofessionel. Hvad angår inddragelse i patientsikkerhed forudsætter denne, at de fagprofessionelle kan rumme patienternes observationer.

\section{Mål 3: Sammenhæng i sundhedsvæsenet}

Målet om at skabe sammenhæng i patientforløb og gode overgange mellem sektorer ligger ligeledes højt på den politiske dagsorden, og også her anses brugerinddragelse som en metode til at nå målet (Danske Patienter et al. 2013; Danske Regioner 2013; Region Midtjylland 2010; Sundhedsstyrelsen 1999, 2005; Regeringen 2014; Ministeriet for Sundhed og Forebyggelse 2014). Patienter og pårørende opfattes som oplagte tovholdere i egne forløb, fordi de antages at have "det store billede" af eller overblik over deres forløb. Patienter der har dokumenteret deres rejse igennem sundhedsvæsenet betragtes derfor i stigende grad som ressourcepersoner, man kan trække på, når man skal forbedre kvaliteten i sundhedsvæsenet - gennem styrket sammenhæng og bedre overgange (Lægeforeningen (U.å); Martin 2010; Timm 2010). En sundhedsfaglig skepsis har været, at det er svært at have tillid til, at patienterne selv har styr på, hvad der er sket i deres forløb (Martin 2010; DSI 2000). En udfordring er også, at de nuværende incitamentsstrukturer og opbygningen af organisationer ikke understøtter målet om sammenhæng (HolmPetersen \& Buch 2012, 2014; Buch, Holm-Petersen \& Hansen 2013).

\section{Mål 4: At begrænse sundhedsudgifterne}

Brugerinddragelse ses i policy dokumenter bl.a. som et middel til at begrænse brugen af sundhedsydelser og til at inddrage patienters og pårørendes egne ressourcer (Ministeriet for Sundhed og Forebyggelse 2014; Regeringen 2013; Danske Patienter et al. 2013; Innovationsrådet et al. 2007; Sundhedsstyrelsen 2005). Uagtet at begrebet patient- og pårørenderessourcer fortsat er åbent og upræcist defineret (Martin \& Hansen 2011), har dette været et mål siden Sundhedsprioriteringsudvalgets rapport i 1977 (Pedersen 2008). Den seneste tids politiske udspil handler om, hvordan borgere kan minimere deres træk på sundhedsvæsenet. Borgeren skal forebygge sygdom. Borgeren eller patienten skal varetage mest muligt af egen behandling selv - af hensyn til samfundets sparsomme ressourcer, men også ud 
fra både behandlingsmæssige og etiske betragtninger om at det er godt at støtte mennesker $i$ at kunne klare sig selv i videst muligt omfang. Brugerinddragelse har forskellige potentialer for at bidrage til at reducere sundhedsudgifter. Fx diverse "gør det selv" tiltag hvor brugerne dels holder sig selv sundere, dels aflaster sundhedsvæsenet. Herudover taler politikere i dag i stigende grad om pårørendeinddragelse - nogle gange forstået som pårørendes inddragelse i løsning af konkrete opgaver. De pårørende italesættes som en ressource, der fremover skal tænkes mere systematisk ind som aflastning af de sundhedsprofessionelle (Region Syddanmark 2011) og de offentlige udgifter. Et andet middel til at tæmme sundhedsudgifterne er brugerinddragelse i kliniske beslutninger (Regeringen 2013; Entwisle et al. 2012). Undersøgelser har nemlig vist, at patienter er mere påholdende i deres efterspørgsel, når de inddrages i de kliniske beslutninger (Coulter 2011). Logikken er blandt andet, at det at dele viden og vidensgrundlag må føre til mere konservative valg i og med, at det bliver mere synligt for patienter og pårørende, at vidensgrundlaget ikke nødvendigvis er entydigt, og at der kan være alvorlige bivirkninger ved en behandling. Et mål med brugerinddragelse er i tråd hermed en mere målrettet og effektiv anvendelse af sundhedsvæsenets ressourcer (Danske Patienter et al. 2013).

Målet om at begrænse sundhedsudgifterne er skabt af administrative og økonomiske behov og italesat på policy niveauet. Det har den udfordring for sundhedsvæsenets ledere, at medarbejderne ikke nødvendigvis finder, at dette mål med brugerinddragelse er vigtigt. Faktisk kan der ligge en udfordring for implementering af brugerinddragelse, hvis de lokalt mister produktion. Afdelinger på fx et hospital måles ikke på og belønnes ikke for, hvorvidt de sparer samfundet penge, men derimod på deres egen driftsøkonomiske formåen. En anden ledelsesmæssig udfordring er, at lederen kan forvente modstand fra patienterne og de pårørende, dels hvis de tolker brugerinddragelsen som en måde at blive ramt af sparekrav. Dels hvis patienter og pårørende ikke selv oplever at have uudnyttede ressourcer, som sundhedsvæsenet kan trække yderligere på. Kronikernes egenomsorgsarbejde kan ses som kronisk hjemmearbejde eller lektier (Mattingly, Grøn \& Meinert 2011; Grøn et al. 2012). Andre studier har vist, at de pårørende udfører et omfattende og overset arbejde i rehabilitering (Navne \& Wiuff 2011) og understreger, at familiers og ægtefællers relationer bruges, trues, støttes og forandres af de nye opgaver, som rehabilitering bringer ind i familier. Studier af pårørende til hjerneskadede eller psykisk syge viser, at behovet for psykosocial støtte og risikoen for depressioner og øget sygelighed i disse grupper er stor (Cederblad et al. 2013; Erlingsson, Magnusson \& Hanson 2012; Wive 2006). Patienter kan også have en 
oplevelse af, at der er tale om en uønsket medikalisering af hverdagslivet (Timm 1997). Dette er blot nogle af de mange modstandsformer, som en ledelses arbejde med brugerinddragelse kan møde, når målet er at spare på sundhedsudgifter.

\section{Må1 5: At håndtere kronikerudfordringen}

Den økonomiske udfordring er bl.a. tiltaget i takt med ændret demografi og ændret sygdomsbillede med flere kronisk syge og multisyge. WHO anbefaler, at brugerinddragelse anvendes som en af flere løsninger på kronikerudfordringen. Dette er i tråd med danske policy dokumenter (Regeringen 2013; Danske Patienter et al. 2013; Innovationsrådet et al. 2007; Sundhedsstyrelsen 2005). Den nye kroniker er ofte en kompleks patient med et komplekst sygdomsbillede som kræver en ny tilgang til patienter (Freil \& Kjær 2012). Sygdom er ikke længere noget, mennesker har eller er i en afgrænset periode af deres liv. Sygdom bliver på den måde en del af mange menneskers permanente tilstand og identitet. Det stiller krav om, at sundhedsvæsenet indrettes på en måde, hvor patienten bliver mindre afhængig af at skulle gå til undersøgelser og kontroller, og hvor sundhedsvæsenet overdrager kompetencer og udstyr til patienten (Anderson 2005, 2010). Man kan også sige, at menneskets hele liv er blevet relevant i en klinisk sammenhæng. I regeringens seneste sundhedspolitiske udspil introduceres patienten nu som borger: "Det moderne behandlingsforløb tager udgangspunkt $\mathrm{i}$ borgerens behov, evner og ønsker. Den enkelte borger skal have hovedrollen i eget sygdomsforløb og inddrages fra start til slut" (Regeringen 2013). Udviklingen med flere kroniske patienter fordrer, at patienten i højere grad ses som borger - frisat fra den traditionelle patientrolle (Freil \& Kjær 2012) og identitet som syg. Den kroniske sygdom bliver i stedet et vilkår, borgeren har. Brugen af ordet borger signalerer, at alle (raske som syge borgere) forventes at være i gang med sundhedsfremmende eller forebyggende aktiviteter, fordi vi alle tilhører kategorien (ansvarlige) borgere.

Brugerinddragelsens mål om at bidrage til at håndtere kronikerudfordringen synes at imødekomme både administrative/økonomiske behov og sundhedsfaglige perspektiver på god behandling. Ledelsesmæssigt har det den betydning, at målet kan understøtte implementering af brugerinddragelsestiltag. Lederen kan stadig forvente modstand fra patienter og pårørende, fordi det ikke er entydigt, om brugerinddragelse med kronikerhåndtering som mål fører til mere brugerindflydelse. I policy dokumenter lægges der op til, at sundhedsvæsenet gennem brugerinddragelse skal støtte patienter i at træffe valg, der fremmer det gode, det rigtige og sunde liv som er til gavn for samfundet. Brugerinddragelse kan på den- 
ne vis ses som et middel til at opnå en bestemt adfærd og et middel til styring af borgerne (Jørgensen et al. 2003; Navne et al. 2012). Man kan derfor tale om brugerstyringens dualitet. På den ene side er der et ønske om, at brugerne i højere grad definerer og styrer ydelserne. På den anden side er der et ønske om, at ydelserne definerer og styrer brugerne som aktive og sundhedsskabende deltagere.

\section{Mål 6: At ændre professionskulturer}

"Lægerne skal ned fra deres piedestal og patienterne op fra deres knæ" (Robert Johnstone ved ENOPE 2012). Mål 6 kan ses som en forudsætning for at mål 1 kan indfries. Der er på samfunds- og policy-plan ikke længere samme grad af tillid til, at fagprofessionerne altid ved bedst. Borgere er blevet mindre autoritetstro (DSI 2000). I sundhedsvæsenet ses tendensen, når patienter og pårørende i stigende grad selv søger informationer eksempelvis på internettet. Tendensen ses også i den stigende mængde af tv-programmer og livstilsbøger, der stiller spørgsmålstegn ved, om medicinske løsninger altid er de rigtige. I den seneste politiske retorik er det i tråd hermed i højere grad op til brugerne at reformere sundhedsvæsenet. Inddragelse af brugerne skal sikre en bedre kvalitet. Og inddragelse af brugerne skal skabe en mere effektiv ressourceudnyttelse (Regeringen 2013). Målet om at udfordre professionskulturerne ligger i New Public Managements fokus på brugeren (Davies 1995; Ferlie 1997; Coulter 2011; Jespersen 1996; Llewellyn 2002; Hunter 1996). New Public Management reformerne indeholder således en intention om at gøre sundhedsvæsenet mindre paternalistisk og udbyderdrevet og mere brugerdrevet samtidig med, at brugerne får mere magt og de professionelle mindre (Hunter 1996). At de fagprofessionelle og deres ledere i højere grad skal føle pligten til effektivt at producere service i overensstemmelse med brugernes behov er en del af grundideen med NPM (Jespersen, Nielsen \& Sognstrup 2000; Peck \& Dickinson 2008). At begynde at tale om brugeren eller borgeren som en der har en viden, der er ligeværdig (Danske Patienter et al. 2013), kan ses som en måde at udfordre fagprofessionernes privilegerede rum på.

Målet med brugerinddragelse om at udfordre professionskulturer knyttes i litteraturen til implementeringsmodstand og har til tider skabt en grundlæggende mistillid til brugerinddragelse og målene hermed. Brugerinddragelse og begreber som patientautonomi er således blevet knyttet sammen med risiko for afprofessionalisering og risiko for, at lægen som fagprofessionel ender som et serviceorgan (Rossel 1997). Sundhedsprofessionelle kan dermed være bekymrede for, at fx fælles beslutningstagning vil true den professionelle autonomi (Coulter 1997; DSI 
2000). Bekymringen afspejles i citatet: "I høj grad er det jo kultur. Hvordan vi er uddannet til at være læger. Det er en flydende overgang, hvordan vi håndterer lægerollen. Hvad vores opgaver egentlig er. Jeg ved ikke, om der er nogle, der tror, at de bliver overflødige. Det kunne man jo godt tro." (Ledende læge i Holm-Petersen \& Navne 2013)

\section{Mål 7: Legitimering og patienttilfredshed}

Brugerinddragelse kan også ses som en måde at skabe legitimering af velfærdsydelser gennem den deltagelse, der ligger heri (Vedung \& Dahlberg 2013). Eller som Ministeriet for Sundhed og forebyggelse skriver: I et offentligt finansieret sundhedsvæsen, er det en værdi i sig selv, at borgerne oplever et system, der både er åbent og demokratisk (2014:2). I en legitimeringsoptik er det derfor væsentligt at argumentere for, at brugerinddragelse fører til mere patienttilfredshed, hvilket flere aktører også har gjort (Innovationsrådet et al. 2007; Ministeriet for Sundhed og Forebyggelse 2014; Regeringen 2013; Socialstyrelsen 2003; Region Nordjylland 2012; Region Syddanmark 2011; Region Midtjylland 2010). Legitimering er et væsentligt mål for offentlige organisationer, fordi legitimering skaber handlerum og bidrager til organisationens overlevelse (Dimaggio \& Powell 1983, 1991; Meyer \& Rowan 1977; Ruef \& Scott 1998). Vi vil i forlængelse heraf argumentere for, at politiske krav om brugerinddragelse afføder et behov for at vise, at brugerinddragelse er noget, man gør. Med andre ord bliver den legitimering, der kommer af at tilpasse sig de krav om aktiviteter, der stilles til sundhedsvæsenet udefra i sig selv et mål med brugerinddragelse. Det er set med policy briller positivt, hvis det fører til mere brugerinddragelse. Eller til mere tilfredse patienter således som også klinikere peger på, at brugerinddragelse gør (ViBIS 2012:11, 2013:22-23). Organisationsteoretisk litteratur om forandring i sundhedssektoren tegner dog et billede af, at reformer og forandringstiltag har en tendens til at føre til handlinger uden det intenderede indhold, når de filteres ned igennem komplekse hospitalsorganisationer (Bentsen et al. 1999; Borum 2003; FLOS 2004; Zuiderent-Jerak 2007; Greenwood et al. 2011; Johansson, Noren \& Wikström 2010). Konsekvensen er, at brugerinddragelsesinitiativer risikerer at være primært legitimeringsprojekter, der forsøger at leve op til krav fra et policyniveau uden andre egentlige mål. 


\section{Målene er ikke ligegyldige for ledelsesindsatsen}

For at kunne lede brugerinddragelse og opstille relevante implementeringsstrategier og succeskriterier er det nødvendigt at være bevidst om målet - eller målene. Målene afføder forskellige forventninger til patientens og dennes potentielle pårørendes roller som brugere. Målet betyder derfor noget for, hvordan de fagprofessionelle og brugerne opfatter relevansen af den ændrede indsats. Og dermed hvilke implementeringsudfordringer ledere må forvente. Medarbejderne i sundhedsvæsenet finder ikke nødvendigvis, at alle syv mål med brugerinddragelse er lige vigtige. Det er fremgået af litteraturen, at der er tale om en væsentlig ledelsesudfordring, når målet med brugerinddragelse er ligeværdigt at dele viden og beslutninger. Tackles denne udfordring ikke, opstår der en reel risiko for "som om" inddragelse.

I undersøgelsen af best brugerinddragelsesledelses practice på danske hospitaler (Holm-Petersen \& Navne 2013) var der på alle tre case afdelinger flere samtidige mål. På Ortopædkirurgisk Afdeling på Frederiksberg Hospital har de igennem en årrække arbejdet med at inddrage deres patienter via kvalitetsmøder og patientdagbog med mål om at skabe en god servicekultur, øge kvaliteten i de accelererede forløb og derigennem øge patienttilfredsheden. Et samtidigt mål har været at sikre afdelingens eksistens og medarbejdernes stillinger. På Epilepsiambulatoriet på Aarhus Universitetshospital, hvor de har deltaget i udviklingen af 'Ambuflex', har et mål været at skabe et kvalitetsløft for patienterne i form at øget brugerstyring, dvs. udvikling af et mere fleksibelt ambulatorium der skal facilitere, at patienterne i højere grad selv definerer hvornår og hvor meget, de har behov for ambulant kontrol frem for et systemgenereret rulleskema. Herudover har det også været et mål at imødekomme et voksende arbejdspres samt at ændre den eksisterende arbejdsdeling (opgavefordeling) mellem sekretærer, sygeplejersker og læger. På Glostrup Hospitals apopleksienhed, hvor de havde udviklet 'Den involverende stuegang', havde ledelsen det mål at gøre stuegangen mere inddragende og ligeværdig og dermed skabe et kvalitetsløft for patienter og pårørende. Men der var også andre ledelsesmæssige mål med initiativet. Herunder at etablere et samlingspunkt efter fusion ved at foretage en faglig opgradering af arbejdet ved at implementere et spændende tiltag. Det var også et mål at skære ned på den tid, der blev brugt på møder og beslutninger uden om patient og pårørende. Endelig var det et mål at leve op til Glostrup Hospitals virksomhedsgrundlag i IPLS (Inter-professionel læring og samarbejde). Initiativet var på denne måde med til at legitimere afdelingen som en, der satte ønskede aktiviteter i gang. De tre case 
afdelinger illustrerer, hvor forskelligartede mål ledelser kan have med at inddrage patienter og pårørende. Nogle af de forskellige mål hang sammen med ledelsesmæssige tanker om, hvad der lokalt skal til for at motivere medarbejdere til den nødvendige gentækning af professionsidentitet og patientsyn. At det ikke er nok i sig selv at ville gøre det bedre for patienterne. At der skal andre arbejdsrelaterede drivkræfter til som eksempelvis arbejdspres.

Til listen over de 7 mål med brugerinddragelse kan vi således på baggrund af den empiriske undersøgelse tilføje: lokale organisatoriske mål. Når "løsningen" brugerinddragelse kobles sammen med konkrete organisatoriske udfordringer eller "problemstrømme" (Cohen, March \& Olsen 1972) øges sandsynligheden dermed for implementeringssucces.

Organisationsteorien har længe påpeget, at organisationer er præget af eksistensen af flere mål på en gang, og at disse mål kan være i konflikt med hinanden (Cyert \& March 1963; Scott 1992). Det er derfor en vigtig ledelsesopgave at gøre sig tanker om og lægge strategier for, hvordan man vil arbejde for at opfylde flere samtidige og måske også modsatrettede mål. Modsætninger er nemlig en væsentlig del af komplekse organisationer (Greenwood et al. 2011). Implementering af brugerinddragelse vil derfor indebære et væsentligt forhandlingsarbejde for ledere i takt med, at de italesætter mål for brugerinddragelse.

\section{Tre modeller, der afspejler forskellige mål for samarbejdsrelationer}

Vi har i artiklen argumenteret for, at det i høj grad er op til lederne i sundhedsvæsenet, hvis den nuværende status på brugerinddragelse skal ændre sig. Vi har også argumenteret for, at ledere skal gøre sig målene med brugerinddragelse klar. Forskellige mål forudsætter forskellig håndtering, og derfor foreslår vi, at indsatsen diskuteres i relation til tre grundmodeller, der afspejler forskellige måder at organisere relationen til patienten: 1) den servicemindede inddragelse, 2) den faciliterende inddragelse og 3) det ligeværdige partnerskab. De tre modeller er formuleret med afsæt i forskning i brugerinddragelse. Positionerne afspejler således tre forskellige udgangspunkter: Om dagsordenen for mødet mellem brugere og sundhedsprofessionelle sættes af henholdsvis lægen, patienten eller begge gennem en forhandling (Emanuel \& Emanuel 1992; Coulter 1997; Entwistle et al. 1998; Jacobsen et al. 2008). 
Den servicemindede inddragelse tænker i højere grad end de to andre modeller på brugeren som en, der vælger at modtage en ydelse. Ekspertisen ligger entydigt hos den fagprofessionelle, men brugeren kan vælge til eller fra. Modellen organiserer relationen til patienten som en forbruger, der i tråd med neoliberale principper og new public management kan forvente en service, der er tilpasset brugerens behov (Asmussen \& Jöhncke 2004; Pedersen 2008). Gennemførslen af patienttilfredshedsmålinger og diverse feedback møder med patienter ligger i tråd med denne models måde at organisere relationen til patienten. Dette er modellen, man kan vælge, hvis man ønsker at indrette sine ydelser sådan, at de i højere grad er indrettet på brugerens præferencer, behov og forventninger til service. Modellen kan i teorien bidrage til opfyldelsen af målene med at sikre en bedre kvalitet, håndtere kronikerudfordringen og derigennem begrænse sundhedsudgifterne. Så længe brugerinddragelse er et vigtigt politisk og organisatorisk mål, vil modellen også opfylde målet om at legitimere sine ydelser. Den servicemindede brugerinddragelse passer godt ind i den måde brugerbegrebet - som først og fremmest et retorisk begreb - er blevet udviklet og anvendt på et politisk, strategisk niveau med særligt fokus på patientrettigheder (Timm 1997; Pedersen 2008).

Modellen stiller ikke spørgsmålstegn ved, at det er den fagprofessionelle, der har "de rigtige svar". Ydelserne er i princippet defineret af systemet og de fagprofessionelle, men de fagprofessionelle arbejder for at optræde serviceminded samt $\mathrm{fx}$ at tænke $\mathrm{i}$ at indrette de fysiske rammer efter brugernes behov, at tilrette informationer til brugernes behov, at indrette ambulatorier med tider der ligger uden for normal arbejdstid - efter brugernes behov m.m. Modellen er den mest enkle af de tre, fordi den ikke skubber til den eksisterende orden. Samtidig kan brugeren få en positiv oplevelse af, at de fagprofessionelle gør en ekstra indsats for at møde hans/hendes behov. Modellen kan på denne vis øge patienttilfredsheden. Som udgangspunkt vil mange igangværende brugerinddragelsestiltag ligge i denne kategori. Der kan være nogle overenskomstmæssige barrierer i forhold til fx at omlægge ydelser til sen eftermiddag eller aften, men ellers er der ikke strukturelle barrierer for at indføre servicerende brugerinddragelse. Modellen er derfor den nemmeste at arbejde ud fra af de tre. 
Den faciliterende inddragelse understøtter brugeren som handlekraftig borger. Her er brugeren i højere grad med til at vurdere sine egne behandlingsbehov. Modellen er teoretisk knyttet sammen med empowerment og patientautonomi. Dette er modellen, man kan vælge, hvis man ønsker at frigive områder inden for sine ydelser til brugerstyring. Den faciliterende inddragelse antager, at størstedelen af behandlings- og plejearbejdet ligger hos borgeren eller patienten selv, hvorfor de fagprofessionelles rolle skal være minimal eller mest af støttende og motiverende karakter. I forhold til beslutningstagning ligger magten til at vælge og træffe beslutninger på disse områder i princippet hos brugeren. Den fagprofessionelle faciliterer blot valgsituationen og stiller fx information, viden, udstyr eller systemer til rådighed for brugeren (Anderson \& Funnell 2005, 2010; Anderson et al. 1995). Lægens rolle bliver som den tekniske ekspert, der informerer og udfører, men ikke beslutter (Jacobsen et al. 2008). Patienten kan på denne vis ses som en empowered post public management forbruger, der vælger at "købe" en ydelse og vælger, hvad der giver mest værdi. Modellen passer dermed godt ind i et post public management fokus på, at værdi ikke er noget, der genereres automatisk ved, at systemet tilbyder standardiserede løsninger (O'Flynn 2007). Omdrejningspunktet i denne slags inddragelsestiltag bliver, i hvilket omfang sundhedsvæsenet kan bero sig på, at patienten bedst ved, hvad han har brug for. Eksempler på denne form for inddragelse er brugerstyrede senge, og brugerstyret kontakt. Modellen kan i teorien bidrage til opfyldelsen af samtlige syv mål, artiklen har identificeret for brugerinddragelsestiltag.

Ledelsesopgaven i denne form for brugerinddragelse bliver uvægerligt fokuseret på system, struktur og organisation samt en forhandling om rollerne som patient og behandler. Hvad angår implementeringsvilkår er der en række udfordringer for at implementere denne model. De væsentligste omhandler følgende tre aspekter: 1) De fagprofessionelles tilbageholdenhed i forhold til at afgive kontrol og ansvar. 2) Patienternes forudsætninger i form af handlings- og beslutningskompetencer. Hvem vil få glæde af modellen? Hvem har ikke forudsætningerne? Hvordan tackles sociale skævvridninger i forudsætninger? Og herunder etiske hensyn. En professionel, der informerer og derefter træder tilbage og overlader den endelige beslutning til patienten, advarer Entwistle imod (Entwistle et al. 2012). Et problem i modellen er, at den forudsætter, at patienten er fuldt bevidst om egne præferencer og værdier og kan gennemskue, hvilke af disse der vil blive berørt af behandlingen (Jacobsen et al. 2008). Der kan også være en ulighedsslag- 
side i, at ikke alle patienter oplever sig beslutningskompetente (Entwistle et al. 2012; DSI 2000). Ifølge Entwistle kræver den gode beslutningsstøtte et relationelt arbejde mellem behandler, patient og eventuelle pårørende. Den professionelles opgave består blandt andet $i$ at vurdere, hvad patientens behov er for beslutningsstøtte for at kunne træffe en beslutning. Dette sker gennem dialog og spørgsmål til patientens værdier, liv og præferencer (Entwistle et al. 2011; Entwistle et al. 2010). 3) Derudover er der den driftsøkonomiske udfordring, at fremmøde eksempelvis honoreres bedre end telefonkonsultationer, telemedicin m.m. (Holm-Petersen \& Navne 2013).

\section{Ligeværdigt partnerskab (princip: delt styring)}

Det ligeværdige partnerskab kendes i den teoretiske litteratur som fælles beslutningstagning (shared decision making) eller i stigende grad som partnerskab. Det grundlæggende element er, at der iscenesættes et ligeværdigt møde og samarbejde mellem patient og sundhedsprofessionel. Dagsordenen sættes af begge parter, og styringen af indholdet er på denne måde delt. Begge parter bidrager således med relevant viden ud fra hver deres perspektiv (Emanuel \& Emanuel 1992; Jacobsen et al. 2008; DSI 2000). Modellen indebærer derfor brugerindflydelse (Timm 1997). Teoretisk er partnerskabstankegangen i tråd med relationel teori. Indenfor det sidste årti har socialvidenskabelige forskere punkteret forestillingen, om det autonome individ som er i stand til at træffe frie valg og gjort opmærksom på, at beslutninger altid er relationelle ( $f x$ Mol 2008). Forestillingen om frie og autonome valg medfører derimod forskydninger i rolle- og ansvarsfordeling, og fører i værste fald til rolle- og ansvars forflygtigelse eller med Anne Marie Mols udtryk "forsømmelse" eller fravær af omsorg/pleje og behandling (ibid.).

Ligeværdigt partnerskab er modellen, man kan vælge, hvis man har et ønske om at kende mere til brugernes ønsker, tanker om deres sygdom samt brugerens perspektiver på den mest relevante behandling for dem. I denne model deles vidensgrundlag og magten til at beslutte. Modellen har respekt for, at brugerne som udgangspunkt kan have væsensforskellige opfattelser af deres sygdom og behov, end sundhedsvæsenet har.

Modellen kan i teorien bidrage til opfyldelsen af samtlige syv mål, artiklen har identificeret for brugerinddragelsestiltag. Modellen er dog kun relevant, hvis man reelt har områder, hvor det er muligt at inddrage brugerne ligeværdigt i beslutninger. Hvis beslutningerne er givet på forhånd, eller den fagprofessionelle på forhånd "ved", hvad brugeren skal vælge, så er forudsætningerne for modellen ikke 
til stede. Formuleringer som: "Jeg ved godt, hvad jeg ville vælge i din situation." eller "Hvis du var min mor..." peger i retning af, at den fagprofessionelle er i gang med overtalelse ved hjælp af tryghedsskabende kommunikation og ikke dialog. En fare ved at arbejde inden for denne overskrift er, at man ender med at bedrive pseudoinddragelse. Tidspres i beslutningssituationen øger sandsynligheden for coaching eller framing (Price, 2009). Det er flere gange blevet konstateret, at Danmark - ligesom andre lande - ikke er nået særlig langt med at implementere fælles beslutningstagning (Jacobsen et al. 2008; Freil \& Knudsen 2009; Regeringen 2013).

Der er en række udfordringer for at udbrede den ligeværdige partnerskabsmodel. Væsentligst synes at være den fagprofessionelle modstand kombineret med, at patienter kan have forskellige ønsker til inddragelse samt styringsmæssige og strukturelle vilkår. I vores empiriske undersøgelse af ledelse af brugerinddragelse på tre danske hospitalsafdelinger blev det tydeligt, at denne inddragelsesform ikke efterspørges fra medarbejdersiden (Holm-Petersen \& Navne 2013). For medarbejderne er klinisk, faglig kvalitet, patient- og pårørendetilfredshed samt forbedringer i arbejdsforhold og indtjeningsgrundlag mere interessante mål.

En ledelsesopgave forbundet med denne model er, på det konkrete plan, udbredelse og implementering af relevante beslutningsstøtteredskaber såvel som kompetenceudvikling i denne form for kommunikation (Elwyn et al. 2013). På mental model eller kulturplanet er udfordringen at gentænke arbejdsdeling, roller og identiteter. Det er dybe strukturer, ledelsen står overfor at håndtere, når man skal argumentere for at dele viden og beslutninger. I det klassiske behandlerpatient-forhold er der indbygget en vidensasymmetri (Coulter 2011; Elwyn et al. 2013; Freidson 1972; Jacobsen et al. 2008; DSI 2000). Undersøgelser har vist, at når de fagprofessionelle skal dele viden og beslutningskompetence med patienter og pårørende, kan det for nogle medføre usikkerhed. Det at dele viden og derigennem magten i relationen berører ikke kun centrale spørgsmål som jurisdiktion, vidensmonopol, men også faglig identitet og fagligt selvværd. Samtidig berører vidensdeling spørgsmål om ansvarsdeling (Tauber 2005).

En ledelsesopgave består også i at fremme og udvikle et fagligt fokus på betydningen af kontakt- og samtalestrukturer. Måden, samtaler mellem læger og patienter er struktureret på, har betydning for henholdsvis opretholdelse eller udligning af (videns)asymmetrien (Jacobsen et al. 2008; Entwistle et al. 2012). En udfordring for at facilitere spørgelystne og aktive patienter, kan være at patienter oplever, at sundhedsprofessionelle reagerer negativt på "for mange" eller "forkerte" spørgsmål (Martin, Rahbæk \& Borst 2013). Elwyn peger i tråd hermed på, at patienter viger tilbage fra at stille spørgsmål af frygt for at blive set som besvær- 
lige - og i frygt for at modtage en dårligere behandling som konsekvens heraf (Elwyn et al. 2013). Mattingly har vist, hvordan pårørende til kronisk syge børn i USA udvikler teknikker til at skrue op og ned for deres aktive deltagelse i barnets behandling, pleje og beslutninger i relation til deres årelange kendskab til de fagprofessionelles forskellige behov for at bibeholde ekspertrollen (se fx Mattingly 1994, 1998, 2010). Det kan derfor ses som en central ledelsesopgave at sikre, at patienter og pårørende kommer til at have en oplevelse af, at det er sikkert at deltage.

\section{Den største ledelsesudfordring}

Et væsentligt træk ved to af de skitserede modeller for brugerinddragelse er, at de forudsætter nytænkning af roller og identiteter. Om patienten mødes som handlings- og beslutningskompetent eller som en, der forventes at være passiv, har betydning for relationen med de fagprofessionelle. Når det i praksis er svært at ændre brugerens rolle, hænger det sammen med, at en ændring heri forudsætter en ændring i de fagprofessionelles rolle i relation til patienten. Der er her en vigtig ledelsesopgave, da sundhedsvæsenet er præget af stærkt institutionaliserede identiteter. Måden, vi taler om patienter på, har, som vi indledningsvist var inde på, konstitutive konsekvenser og meddefinerer et handlerum. Patientbegrebet er defineret som en given rolle i et givent handlerum i relation til det professionelle behandlingssystem og de professionelle behandlere. Goffman har fx vist, at hospitalets orden udstikker et på forhånd givet handlerum for den enkelte - for den syge og for behandleren - og for mødet imellem dem (Goffman i Timm 1997). Det betyder, at vi ikke bare kan opfinde nye roller fra den ene dag til den anden, fordi både patienter, borgere, brugere og de sundhedsprofessionelle allerede "ved", hvad det vil sige at være syg. Og hvilke roller det er passende at "spille" i denne sammenhæng. Man kan derfor ikke se brugerrollen som uafhængig af den professionelle rolle, fordi de nødvendigvis spiller støtteroller for hinanden (Gergen 1997). I dag er det ikke længere givet, at vi mener det samme, når vi anvender ordet patient. Når vi begynder at arbejde med brugerinddragelse, har vi allerede taget hul på at definere patienten på nye måder. Disse definitionsprocesser finder sted i forbindelse med løsningen af konkrete udfordringer, hvor der formuleres nye forventninger til og forståelser af patienten (Kjær \& Reff 2010). I det nuværende sundhedsvæsen omtales patienterne i stigende grad som aktive brugere, der forventes selv at tage et ansvar, men i denne omtale ligger der en forventning om et identitetsskifte. Praktisering af patientinddragelse forudsætter derfor nytænk- 
ning af såvel patientrollen som af de fagprofessionelles roller. Patientinddragelse i praksis berører dermed centrale forhold som identitet og autonomi.

Et vilkår for ledelse af brugerinddragelse er, at uanset hvilken rolle vi tiltænker brugerne, så indgår brugerinddragelse i en historisk sammenhæng, hvor der allerede er en række forståelser og forventninger til, hvad det vil sige at være patient og/eller bruger. Den største ledelsesudfordring af alle i forbindelse med brugerinddragelse er derfor lederens rolle i forhold til at inspirere til, udvikle værktøjer til og stille krav om en gentænkning af de etablerede roller og identiteter.

Uanset hvilken model der vælges, bliver ledelsesopgaven at sikre kompetencer og stadig faglig udvikling i patientinddragende kommunikationsformer. Ledelsesrollen i forhold til brugerinddragelse består derudover i at omsætte brugerinddragelse i arbejdsorganiseringen, definere brugerinddragelse som en arbejdsopgave, have fokus herpå ved ansættelser og skabe de nødvendige økonomiske forudsætninger. Patientinddragelse vil på denne vis forudsætte ledelsesmæssig prioritering Det betyder også, at hvis brugerinddragelse har negative konsekvenser for driftsbudgettet, så er det en særlig udfordring at implementere brugerinddragelse jf. udfordringen med, at nogle former for aktiviteter honoreres bedre af DRG-systemet end andre. I sådanne tilfælde forudsætter implementering af brugerinddragelse opbakning langt op i ledelsessystemet.

\section{Referencer}

Abbott, A. (1988). The system of the professions. An essay on the division of expert labor. Chicago: The University of Chicago Press.

Andersen, V., Lipczak, H \& Ammundsen I.N. (2011). Involvering af patienter i patientsikkerhed. Litteraturgennemgang 2005 - 2010. Hvidovre: Dansk Selskab for Patientsikkerhed.

Anderson, R.M. \& Funnell, M.M. (2010). Patient empowerment: myths and misconceptions. Patient Education and Counseling, 79(3), 277-282.

Anderson, R.M. \& Funnell, M.M. (2005). Patient empowerment: reflections on the challenge of fostering the adoption of a new paradigm. Patient Education and Counseling, 57(2), 153-157.

Anderson, R.M., Funnell, M.M., Butler, P.M., Arnold, M.S., Fitzgerald, J.T. \& Feste, C.C. (1995). Patient empowerment: results of a randomized controlled trial. Diabetes Care, 18(7), 943-949. 
Asmussen, V. \& Jöhncke, S. (2004). Brugerperspektiver - fra stofmisbrug til socialpolitik. Aarhus: Aarhus Universitetsforlag.

Bate, P. \& Robert, G. (2006). Experience based design: from redesigning the system around the patient to co-designing services with the patient. Quality and Safety in Health Care, 15(5), 307-310.

Borum, F. (ed.) (2003). Ledelse i sygehusvæsenet. København: Handelshøjskolens Forlag.

Brante, T. (1988). Sociological approaches to the professions. Acta Sociologica, 31(2), 119-142.

Buch, M.S., Holm-Petersen, C. \& Hansen, E.B. (2013). Status for Region Hovedstadens forløbsprogrammer for kronisk obstruktiv lungesygdom (KOL) og type 2 diabetes. København: KORA.

Cederblad, M., Nevéus, T., Åhman, A., Österlund Efraimsson, E. \& Sarkadi, A. (2013). "Nobody Asked Us if We Needed Help": Swedish parents experiences of enuresis [Epub ahead of print]«. Journal of Pediatric Urology, pii, 14775131(13)00163-0 no. Jul 11, available online.

Coulter, A. (1997). Partnerships with patients: the pros and cons of shared clinical decision-making. Journal of Health Services Research and Policy, 2(2), 112-119.

Coulter, A. (2011). Engaging Patients in Health Care. Maidenhead: Open University Press.

Coulter, A. (2012). Transforming health and social care through patient empowerment - the policy challenge. Præsentation fra: ENOPE: 1st European Conference on Patient Empowerment, http://www.enope.eu/activities/congress-2012. aspx .

Cyert, R.M. \& March, J.G. (1963). A behavioral theory of the firm. New Jersey: Prentice Hall.

Danske Patienter, Kommunernes Landsforening, Sundhedsstyrelsen \& Danske Regioner (2013). Borgernes sundhedsvæsen. København.

Danske Regioner (2013). Bidrag til en ny sundhedspolitik. København: Danske Regioner.

Davis, R.E., Jacklin, R., Sevdalis, N., et.al. (2007) Patient involvement in patient safety: what factors influence patient participation and engagement? Health Expect, 10, 259-67.

Davies, C. (1995). Gender and the Professional Predicament in Nursing. Buckingham: Open University Press.

De Silva, D. (2014). Helping measure person-centred care. A review of evidence about commonly used approaches and tools used to help measure person-centred care. London: Health Foundation. 
Det nationale råd for kvalitetsudvikling i sundhedsvæsenet (2002). National strategi for kvalitetsudvikling $i$ sundhedsvæsenet. Fælles mål og handleplan 2002 - 2006. København: Sundhedsstyrelsen.

Dimaggio, P.J. \& Powell, W.W. (1983). The iron cage revisited: Institutional isomorphism and collective rationality in organizational fields. American Sociology Review, 48, 147-160.

Dimaggio, P.J. \& Powell, W.W. (1991). The new institutionalism in organizational analysis. Chicago: The University of Chicago Press.

DSI - Institut for Sundhedsvæsen (2000). Fælles beslutningstagning. Et litteraturstudium om en behandlingsbeslutningsmodel. København: DSI - Institut for Sundhedsvæsen.

Edwards, A. \& Elwyn, G. (Eds.) (2009). Shared decision-making in health care. Achieving evidence based patient choice. 2nd ed. Oxford: Oxford University Press.

Elwyn, G., Grande, S.G., Gittell, J.H., Godfrey, M.M. \& Vidal, D.C. (Eds.) (2013). Are we there yet? Case studies of implementing decision support for patients. Hanover, New Hampshire: The Dartmouth Center for Health Care Delivery Science; The Dartmouth Institute for Health Policy and Clinical Practice.

Emanuel, E.J. \& Emanuel, L.L. (1992). Four models of the physician-patient relationship. Journal of the American Medical Association, 267, 2221-2224.

ENOPE (2012). ENOPE 1st European Conference on Patient Empowerment.

Entwistle, V.A., Cribb, A. \& Watt, I.S. (2012). Shared decision-making: Enhancing the clinical relevance. Journal of the Royal Society of Medicine, 105(10), 416-421.

Entwistle, V.A., McCaughan, D., Watt, I.S., Birks, Y., Hall, J., Peat, M., Williams, B. \& Wright, J. (2010). Speaking up about safety concerns: multi-setting qualitative study of patients' views and experiences. Quality and Safety in Health Care, 19(6), e33-e33.

Entwistle, V.A., France, E.F., Wyke, S., Jepson, R., Hunt, K., Ziebland, S. \& Thompson, A. (2011). How information about other people's personal experiences can help with healthcare decision-making: a qualitative study. Patient Education and Counseling, 85(3), e291-e298.

Entwistle, V.A., Sowden, A.S. \& Watt, I.S. (1998). Evaluating interventions to promote patient involvement in decision-making: by what criteria should effectiveness be judged? Journal of Health Services Research and Policy, 3(2), 100-107.

Erlingsson, C.L., Magnusson, L. \& Hanson, E. (2012). Family Caregivers' Health in connection with providing care. Qualitative health research, 22(5), 640-655. 
Ferlie, E. (1997). Large-scale organizational and managerial change in health care: a review of the literature. Journal of Health Services Research and Policy, 2(3), 180189.

FLOS - Forskningscenter for Ledelse \& Organisation i Sygehusvæsenet (2004). Forskning i sygehuse under forandring. Hovedpointer fra fem års studier af ledelse og organisering $i$ det danske sygehusvæsen. Frederiksberg: Nyt fra Samfundsvidenskaberne.

Freidson, E. (1983). The theory of the professions: State of the art. I R. Dingwall, \& P. Lewis (Eds.), The Sociology of the Professions. (pp. 19-37). London, UK: The Macmillan Press.

Freidson, E. (1986). Professional powers. A study of institutionalization of formal knowledge. Chicago: The University of Chicago Press.

Freil, M. \& Kjær, P. (2012). Patientinddragelse i et optimeret sundhedsvæsen i L. Christensen, P. Christiansen, \& B. Dam (Eds.), Sund ledelse. 19 bud på god sygehusledelse, (pp. 113-122). København: Danske Regioner; Dansk Selskab for ledelse i Sundhedsvæsenet.

Freil, M \& Knudsen, J.L. (2009). Brugerinddragelse i sundhedsvæsenet. Ugeskrift for Læger, 171(20), 1663-1666.

Gergen, K.J. (1997). Virkelighed og relationer. Virum: Dansk Psykologisk Forlag.

Greenfield, S., Kaplan, S.; Ware, J.E. Jr. (1985) Expanding patient involvement in care. Effects on patient outcomes. Annals of Internal Medicine, 102(4), 520-528.

Greenwood, R., Raynard, M., Kodeih, F., Micelotta, E. \& Lounsbury, M. (2011). Institutional complexity and organizational responses. The Academy of Management Annals, 5(1), 317-371.

Grøn, L., Franck, E.B., Rahbek, L.E.B., Nielsen, M. \& Buch, M.S. (2012). Egenomsorg og patientuddannelse i grænsefladen mellem medicin og humaniora. København: Dansk Sundhedsinstitut.

Guadagnoli E, Ward P. (1998). Patient participation in decision-making. Social Science and Medicine, 47(3), 329-39.

Hansen, H. P. \& Tjørnhøj-Thomsen, T. (2014). Kræft og håbsarbejde. Tidsskrift for Forskning i Sygdom og Samfund, 20, 77-92.

Hibbard, J.H. \& Cunningham, P.J. (2008) How engaged are consumers in their health and health care, and why does it matter? Research Brief (8), 1-9.

Hibbard, J.H., Mahoney, E.R., Stock, R. et al. (2007). Do increases in patient activation result in improved self-management behaviors? Health Services Research, 42, 1443-63. 
Hoff, J. (1997). Brugerindflydelse: Udviklingen i Danmark. I U. Hjelmar (ed.), Etisk regnskab. Værdistyring og resultatmåling (pp. 17-26). København: Frydenlund/erhverv.

Hoggett, P. (2006). Conflict, ambivalence, and the contested purpose of public organizations. Human Relations, 59(2), 175-194.

Holm-Petersen, C. \& Buch, M.S. (2012). Midtvejsevaluering af sundhedsaftale 20102014 i Region Sjælland. København: Dansk Sundhedsinstitut.

Holm-Petersen, C. \& Buch, M.S. (2014). Litteratur om ledelse af samarbejde på tværs af sektorer i sundhedsvæsenet. København: KORA.

Holm-Petersen, C. \& Navne, L. E. (2013). Ledelse af brugerinddragelse. Tre casebaserede eksempler. København: KORA.

Hunter, D.J. (1996). The changing roles of health care personnel in health and health care management. Social Science and Medicine, 5, 799-808.

Innovationsrådet, Patientforum, Danske Regioner, Oxford Health Alliance \& Mandag Morgen (2007). Brugernes sundhedsvæsen. Oplæg til en patientreform. København: Mandag Morgen.

Institute of Medicine (2000). To err is human: building a safer health system. Washington DC: National Academy Press.

Jacobsen, C.B. \& Petersen, A. (2009). At skabe muligheder for brugerinddragelse i daglig klinisk praksis. København: Dansk Sundhedsinstitut.

Jacobsen, C.B., Pedersen, V.H. \& Albeck, K. (2008). Patientinddragelse mellem ideal og virkelighed - en empirisk undersøgelse affrelles beslutningstagning og dagligdagens møder mellem patient og behandler. København: Sundhedsstyrelsen, Monitorering og Medicinsk Teknologivurdering; Dansk Sundhedsinstitut.

Järvinen, M. \& Mik-Meyer, N. (2003). Indledning: At skabe en klient in At skabe en klient, M. Järvinen, \& N. Mik-Meyer (Eds.). København: Hans Reitzels Forlag.

Jespersen, P.K. (1996). Bureaukratiet - magt og effektivitet. København: Jurist og økonomforbundets Forlag.

Jespersen, P.K., Nielsen, L.M. \& Sognstrup, H. (2000). Sygehuse i forandring. Ydre pres, omstillinger og professionelle projekter. Aalborg: Aalborg Universitet.

Jest, P. (2005). Patientens forløb frem for patientforløb. Flyt fokus fra standardiserede patientforløb til individuelle forløb. Ugeskrift for Læger, 167(44), p. 4208.

Johansson, I. Noren, L. \& Wikström, E. (2010). Patient-centred care: the Nordic position. International Journal of Public Sector Management, 23(4), 325-330.

Joint Commission Ressources (2006). Patients as partners: how to involve patients and families in their own care. Chicago: Joint Commission on Accreditation of Healthcare Organizations. 
Jørgensen, T.B., Togeby, L., Goul Andersen, J., Munk Christiansen, P. \& Vallgårda, S. (2004). Magt og demokrati i Danmark. Hovedresultater fra Magtudredningen, Aarhus: Aarhus Universitetsforlag.

Kjær, P. \& Reff, A. (2010). Ledelse gennem patienten: nye styringsformer i sundhedsvæsenet. København: Handelshøjskolens Forlag.

Knudsen, M. \& Bentsen, E.Z. (Eds.) (2010). Kamp, kommunikation og kompleksitet: Ledelse og fortolkninger i sundhedsvæsenet. København: Handelshøjskolens Forlag.

Llewellyn, S. (2002). "Two-way windows". Clinicians as medical managers. Organization Studies, 22 (4), 593-623.

Lupton, D. (1994). Medicine as culture. Illness, disease and the body in western societies. London, UK: SAGE.

Lægeforeningen [U.å.]. Sammenhængende patientforløb. Kontinuitet - kerneydelse - koordination - kommunikation. København: Lægeforeningen.

Mandag Morgen (2014). Patienter savner dialog med læger. Mandag Morgen, (31).

Martin, H.M. (2010). Er der styr på mig? Sammenhængende patientforløb fra patientens perspektiv. København: Dansk Sundhedsinstitut.

Martin, H.M. \& Hansen, J. (2011). To opfattelser af patientressourcer. Sygeplejersken, 111(20), 56-59.

Martin, H.M. \& Larsen, J. (2012). Patient involvement in patient safety: A literature review on European primary care. København: Dansk Sundhedsinstitut.

Martin, H.M., Navne, L.E. \& Lipczak, H. (2013) Involvement of patients with cancer in patient safety: a qualitative study of current practices, potentials and barriers. BMJ Quality \& Safety 2013; 0:1-7. Doi:10.1136.

Martin, H.M., Rahbæk, A.E. \& Borst, L. (2013). Patientoplevelser i KOL- og type 2 diabetesforløb. Delundersøgelse i evaluering af forløbsprogrammernes implementering $i$ Region Hovedstaden. København: KORA.

Mattingly, C. (1998). Healing Dramas and Clinical Plots: The Narrative Structure of Experience. Cambridge, MA: Cambridge University Press.

Mattingly, C. (2010). The paradox of Hope: Journeys through a clinical borderland. Berkeley, CA: University of California Press.

Mattingly, C., \& Fleming, M. (1994) Clinical Reasoning: Forms of Inquiry in a Therapeutic Practice. Philadelphia, PA: F. A. Davis Press.

Mattingly, C., Grøn, L. \& Meinert, L. (2011). Chronic homework in emerging borderlands of healthcare. Culture, Medicine, and Psychiatry, 35(3), 347-375.

Mendick, N., Young, B., Holcombe, C. \& Salmon, P. (2010). The ethics of responsibility and ownership in decision-making about treatment for breast cancer: 
triangulation of consultation with patient and surgeon perspectives. Social Science \& Medicine, 70(12), 1904-1911.

Mendick, N., Young, B., Holcombe, C. \& Salmon, P. (2011). Telling "Everything" but not "Too Much": The Surgeon's Dilemma in Consultations about Breast Cancer. World journal of surgery, 35(10), 2187-2195.

Meyer, J.W. \& Rowan, B. (1977). Institutionalized Organizations: Formal structure as myth and ceremony. American Journal of Sociology, 83, 340-63.

Ministeriet for Sundhed og Forebyggelse (2014). Dialogpapir om øget inddragelse af patienter og pårørende. København: Ministeriet for Sundhed og Forebyggelse.

Mol, A. (2008). The logic of care. Health and the problem of patient choice. New York: Routledge.

Navne, L; Vinge, S \& Thorsen, M.K. (2012) Patientrettet forebyggelse: Et oversigtsnotat over modeller og effekter af indsatser til patienter med KOL, Type 2-Diabetes og Hjertekarsygdom i sygehusregi. København: Dansk Sundhedsinstitut.

Navne, L.E., Nielsen, S. \& Jacobsen C (2011). Forventningssamtalen. Et brugerinddragelsestiltag på Glostrup Hospital, N38. København: Dansk Sundhedsinstitut.

Navne, L.E. \& Wiuff, M.B. (2011). Opgavefordeling mellem borgere, pårørende og fagpersoner i rehabilitering. København: Dansk Sundhedsinstitut.

O'Flynn, J. (2007). From public management to public value: Paradigmatic change and managerial implications. The Australian Journal of Public Administration, 66(3), 353-366.

Parsons, T. (1939). The professions and social structure. Social Forces, 17(4), 457-467.

Peck, E. \& Dickinson, H. (2008). Managing and leading in inter-agency settings. Bristol: The Polity Press.

Pedersen, L. (2011). Patientinddragelse - refleksion, læring, innovation og ledelse. København: Hans Reitzels Forlag.

Pedersen, K.Z. (2008). Patientens politiske diskurshistorie (forskningsrapport). København: Center for Health Management, Copenhagen Business School.

Price, C. (2009). A devil's advocate: Do patients really want shared decision-making? I Edwards, A. \& Elwyn, G. (Eds.) (2009). Shared decision-making in health care. Achieving evidence based patient choice (pp. 363-368). 2nd ed. Oxford: Oxford University Press.

Rahbek, I. \& Rønberg, C. (2010). Patientens svære kamp - om patientinvolvering. I M. Knudsen \& E.Z. Bentsen (Eds.) (2010). Kamp, kommunikation og kompleksitet: Ledelse og fortolkninger $i$ sundhedsvæsenet. (pp. 43-64). København: Handelshøjskolens Forlag. 
Rangachari, P., Bhat, A. \& Seol, Y. (2011). Using the "customer service framework" to successfully implement patient-and family-centered care. Quality Management in Healthcare, 20(3), 179-197.

Regeringen (2014). Jo før - jo bedre. Tidlig diagnose, bedre behandling og flere gode leveår for alle. København: Regeringen. Regeringen (2013). Mere borger, mindre patient. Et stærkt fælles sundhedsvæsen. København: Ministeriet for Sundhed og Forebyggelse.

Region Hovedstaden (2007). Kvalitetsstrategi for Region Hovedstaden 2007-2009. [Hillerød]: Region Hovedstaden.

Region Midtjylland (2010). Kvalitetsstrategien på sundhedsområdet i Region Midtjylland 2010-2013. Viborg: Region Midtjylland.

Region Nordjylland, [2012]. Strategi for sundhedsområdet 2014. Version 1. [Aalborg]: Region Nordjylland.

Region Syddanmark (2011). Strategi for kvalitetsudvikling i sundhedsvæsenet $i$ Region Syddanmark 2011 - 2014. Vejle: Region Syddanmark.

Robinson A, Thomson R. (2001) Variability in patient preferences for participating in medical decision making: implication for the use of decision support tools. Quality in Health Care, BMJ Quality and Safety 10 Suppl. 1, i34-i38.

Rossel, P. (1997). Hvorledes begreber og principper kan forhekse forstanden. $M a ̊-$ nedsskrift for Praktisk Lagegerning, 75, 1419.

Rueff, M. \& Scott, R.W. (1998). A Multidimensional Model of Organizational Legitimazy: Hospital Survival in Changing Institutional Environments. Administrative Science Quarterly, 43(4), 877-904.

Scott, R.W. (1992). Organizations. Rational, natural and open systems. Englewood Cliffs: Prentice-Hall, Inc.

Schwappach, D.L. (2009). Engaging patients as vigilant partners in safety: a systematic review. Medical Care Research and Review, 67, 119-48.

Socialstyrelsen (2003). Samarbejde mellem amt og kommune - om genoptræning af ældre, Socialstyrelsen, København.

Sundhedsstyrelsen (1999). Patientforløb og kvalitetsudvikling. København: Sundhedsstyrelsen.

Sundhedsstyrelsen (2005). Kronisk sygdom. Patient, sundhedsvæsen og samfund. Forudsætninger for det gode forløb. København: Sundhedsstyrelsen.

Swensen S, Pugh M, McMullan C, \& Kabcenell A. (2013). High-Impact Leadership: Improve Care, Improve the Health of Populations, and Reduce Costs. IHI White Paper. Cambridge, Massachusetts: Institute for Healthcare Improvement. 
Tauber AI. (2005). Patient autonomy and the ethics of responsibility. Cambridge, Massachusetts: The MIT press.

The Joint Commission (2007). "What did the doctor say?" Improving health literacy to protect patient safety. Healthcare at the Crossroads Report Series. Oakbrook Terrace, IL: The Joint Commission.

Timm, H.U. (1997). "Patienten i centrum«, Brugerundersøgelser, lægperspektiver og kvalitetsudvikling. DSI rapport, vol. 97.

Timm, H.U. (2010). Sammenhængende forløb i sundhedsvæsenet. København: Videnscenter for Sammenhængende Forløb. Professionshøjskolen Metropol.

Van Maanen, J. \& Barley, S. (1984). Occupational communities: Culture and control in organizations in B. Staw, \& L. Cummings (Eds.) Research in organizational behavior, vol. 6 ed., CT: JAI Press, Greenwich, 287-366.

Vedung, E. \& Dahlberg, M. (2013). Demokrati och brukarutvärdering. Lund: Studentlitteratur AB.

Videnscenter for Brugerinddragelse (2012). Hvad er brugerinddragelse i sundhedsvæsenet? København: ViBIS.

Videnscenter for Brugerinddragelse (2013). Sundhedsprofessionelles forståelser af patientinddragelse. En kvalitativ undersøgelse. København: ViBIS.

Vincent, CA \& Coulter, A. (2002). Patient safety: what about the patient? Quality and Safety in Health Care. 11(1), 76-80.

Wagner, E.H., Austin, B.T., Davis, C., Hindmarsh, M., Schaefer, J. \& Bonomi, A. (2001). Improving chronic illness care: translating evidence into action. Health affairs, 20(6), 64-78.

Weingart, S.N., Zhu, J., Chiappetta L., et.al. (2011). Hospitalized patients' participation and its impact on quality of care and patient safety. International Journal for Quality in Health Care, 23, 269-77.

Wiig, S. et al. (2013). Investigating the use of patient involvement and patient experience in quality improvement in Norway: Rhetoric or reality? BMC Health Services Research, 13(1), 206-219.

Wiuff, M.B., Navne, L.E. \& Olesen, E. (2010). Rehabilitering på borgernes præmisser. København: Dansk Sundhedsinstitut.

Wive, L.B. (2006). Hvad ved vi om pårørende? Et litteraturstudie. Brøndby: Hjerneskadeforeningen.

Zuiderent-Jerak, T. (2007). Preventing implementation: Exploring interventions with standardization in healthcare. Science as Culture. 16(3) 311-329. 